\title{
Skimun fyrir krabbameini í blöðruhálskirtli
}

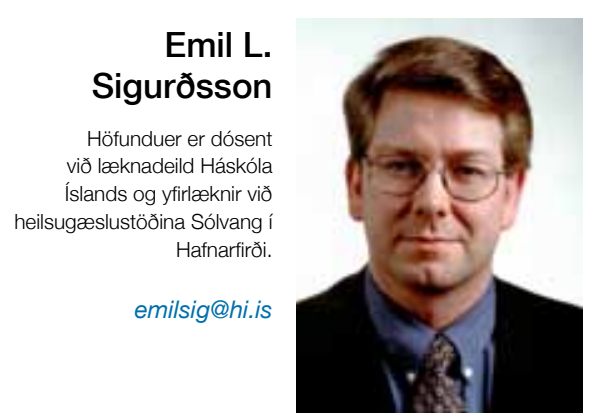

Krabbamein í blöðruhálskirtli er eitt algengasta krabbamein meðal karla. Mikilvægi pess að greina krabbamein snemma til pess að bæta horfur og lífsgæði er augljóst. Pær aðferðir sem notaðar hafa verið til pess varðandi blöðruhálskirtilskrabbamein hafa fyrst og fremst verið preifing á kirtlinum og blóðprufa með mælingu á sérhæfðum hvata (PSA). Preifing á kirtlinum sem skimunartæki hefur ekki sannað gildi sitt en rannsóknir síðari ára hafa beinst að hugsanlegu notagildi PSA við skimun. Viðfangsefnið er hins vegar afar snúið par sem blöðruhálskirtilskrabbamein eru í eðli sínu misslæm, sum mjög banvæn en önnur hafa sennilega hvorki áhrif á lífslíkur né lífsgæði. Síðarnefndu æxlin eru í raun pess eðlis að pað er mjög vafasamt að pað gagnist neinum að pau finnist. Pví miður höfum við í dag hvorki tæki né tól til að greina aðeins pau æxli sem við pyrftum nauðsynlega að finna sem fyrst.

Tvær stórar rannsóknir eru í raun hornsteinninn að okkar vitneskju um gagnsemi kembileitar meðal einkennalausra karla. Önnur rannsóknin, European Randomized Study of Screening for Prostate Cancer (ERSPC), birti nýlega framhaldsniðurstöður sem voru í raun hliðstæðar fyrri niðurstöðum peirrar rannsóknar, pað er 21\% lækkun á dánartíðni vegna blöðruhálskirtilskrabbameins hjá peim sem voru í skimunarhópi, en kembileitin hafði hins vegar engin áhrif á heildardánartíðni. ${ }^{1}$ Hin rannsóknin, Prostate, Lung, Colorectal and Ovarian Cancer Screening Trial (PLCO), sýndi að ekki var neitt gagn að kembileit að blöðruhálskirtilskrabbameini. ${ }^{2}$ Pó nið- urstöður pessara tveggja rannsókna séu að sumu leyti misvísandi um dánartíðni vegna blöðruhálskirtilskrabbameins, önnur sýnir lækkun en hin ekki, tókst í hvorugri rannsókninni að sýna fram á jákvæð áhrif á heildardánartíðni. Niðurstöður sænskrar rannsóknar sem birtist fyrir ári síðan voru einnig pær að kembileit leiddi ekki til lækkunar á dánartíðni. ${ }^{3}$

Hafa verður í huga að til að koma í veg fyrir eitt dauðsfall vegna blöðruhálskirtilskrabbameins parf að skima um 1400 og meðhöndla um 50. Skimun og meðferð geta hins vegar leitt til pess að við ofgreinum, og aukaverkanir vegna rannsókna og meðferðar eru vel pekktar, svo sem sýkingar, pvagleki, ristruflanir og jafnvel dauðsföll.

Læknar standa pví frammi fyrir erfiðu viðfangsefni pegar kemur að pví að aðstoða einkennalausa karla sem óska eftir skimun fyrir blöðruhálskirtilskrabbameini. Ekki ætti að skima neinn án pess að fyrst fari fram upplýst umræða um kosti og galla og til hvers rannsóknin geti leitt. Slík umræða er hins vegar ekki auðveld og tekur bæði tíma og kallar á að læknar sýni pörfum og óskum skjólstæðinganna skilning. Við ákvörðun um hvort mæla eigi PSA parf meðal annars að hafa í huga aldur viðkomandi og ættarsögu og svo er auðvitað alltaf spurning hverjir séu í raun einkennalausir og hverjir með einhver lítil og hægt vaxandi einkenni sem gætu skýrst af góðkynja stækkun á blöðruhálskirtli. Sumir karlar vilja gera allt til að greina krabbamein í blöðruhálskirtli, jafnvel taka pá áhættu að meinsemd sé greind sem væri betur ógreind, auk hættu á fylgikvillum greiningar og meðferðar. Aðrir kunna að vilja fylgja peim ráđum sem klínískar leiðbeiningar og yfirlýsing landlæknis gefa. ${ }^{4}$ Karlar ættu pó að eiga kost á að fara í PSA-mælingu en einungis eftir upplýsta umræðu. Раð er hins vegar bæði fjárhagslega og faglega ósættanlegt að senda einstaklinga í rannsóknir án gagnrýninnar hugsunar. Bæði er unnt að spara fjárútlát hjá hinu opinbera og gera skjólstæðingum okkar meira gagn með markvissari nýtingu á peim rannsóknarmöguleikum sem við höfum. PSA-mælingar eru í dag mikilvægar í vissum tilvikum en hafa ekki sannað sig við kembileit meðal einkennalausra.

Skimun fyrir blöðruhálskirtilskrabbameini hefur verið skoðuð í 5 stórum rannsóknum, bæði með einu prófi og endurteknum mælingum með ákveðnu millibili. Pá hafa mismunandi gildi á PSA verið prófuð til að kanna hvaða gildi sé heppilegast að miða við til að fanga pá sem hefðu hugsanlega gagn af frekari rannsóknum. Jafnframt hafa rannsóknir verið gerðar á notagildi preifingar og ómskoðunar. Pessum rannsóknum öllum hefur mistekist að sýna fram á gagnsemi skimunar og flestar reyndar sýnt frekar fram á skaðsemi.

Nýlega uppfærðar klínískar leiðbeiningar mæla pví gegn kembileit meðal einkennalausra karlmanna. $^{5}$

Enginn velkist í vafa um nauðsyn pess að rannsaka vel pá karlmenn sem eru með einkenni sem hugsanlega gætu stafað af blöðruhálskirtilskrabbameini, vandamálið er hins vegar flóknara pegar kemur að pví að leiðbeina körlum sem eru án einkenna en leita til lækna, meðal annars til að vita hvort peir séu með slík krabbamein.

Pví miður höfum við í dag hvorki sterkan vísindalegan grunn né nauðsynleg greiningartæki til að réttlæta skimun fyrir krabbameini í blöðruhálskirtli.

\section{Heimildir}

1. Schröder FH, Hugosson J, Roobol MJ, Tammela TL, Ciatto $\mathrm{S}$, Nelen V, et al. Prostate-cancer mortality at 11 years of follow-up. N Engl J Med 2012; 366: 981-90.

2. Andriole GL, Grubb RL, Buys SS, Chia D, Church TR, Fouad MN. Mortality Results from a Randomized Prostate-Cancer Screening Trial. N Engl J Med 2009; 360: 1310-9.

3. Sandblom G, Varenhorst E, Rosell J, Löfman O, Carlsson P. Randomised prostate cancer screening trial: 20 year follow-up. BMJ 2011; 342: d1539.

4. landlaeknir.is/lisalib/getfile.aspx?itemid $=4959$ - mars 2012.

5. U.S. Preventive Services Task Force. Screening for Prostate Cancer: U.S Preventive Services Task force Recommendation Statement. DRAFT. uspreventiveservicestaskforce.org/uspstf12/prostate/draftrecprostate.htm - mars 2012.

Screening for Prostate Cancer Emil L. Sigurdsson Associate Professor Department of Family Medicine University of Iceland

Solvangur Health Care Center, Hafnarfjordur, Iceland 